\title{
The Impact of State Regulations on the Costs of Public School Construction
}

Jeffrey M. Vincent and Paavo Monkkonen

\begin{abstract}
A B S T R ACT
Spending by states and local school districts on school construction has increased dramatically over the last decade, not only because more and higher-quality schools are being built, but also because construction costs have increased by an unprecedented degree. Many states struggle to afford the new schools needed in local communities. The emerging body of academic literature studying the determinants of school construction costs focuses on the impact of prevailing wage laws; however, there are several other state-level school construction regulations that have as much potential cost impact as wage laws. In this article, we measure the impacts of three regulations on the costs of construction in a model that incorporates a more comprehensive set of project and locality characteristics than previous research. Using a database of nearly 3,000 schools constructed nationwide from 1995 to 2004, we find that when regulations are considered as additive, construction costs were $11 \%$ higher for each additional state regulation. However, we show that when combinations of regulations are considered separately, states with all three regulations have construction costs that are roughly $30 \%$ higher than states with none of the three regulations. We also find that prevailing wage laws are not the regulation with the largest cost impact. We conclude that the effects of regulation on school construction costs are more complicated than what previous research suggests. Therefore, rather than understanding the impacts of individual regulation as contributing to marginal increases in costs for each additional regulation, it is the whole regulatory environment of a place that has complex impacts on costs. We assert that three key research advances are needed in order to better address the cost of school construction: first, analysis should incorporate more detailed projectlevel data; second, analysis of the costs of state regulation need to be measured
\end{abstract}

Jeffrey M. Vincent, PhD, is the Deputy Director for the Center for Cities \& Schools at the University of California-Berkeley, and Paavo Monkkonen is a $\mathrm{PhD}$ candidate at the University of CaliforniaBerkeley's Department of City and Regional Planning.

JOURNAL OF EDUCATION FINANCE | 35:4 SPRING 2010 313-331 313 
against the benefits of the better "product" realized by these regulations; and third, a better understanding of the interactions among regulations within a state's whole regulatory environment is needed.

\section{IN TRODUCTION}

The public education construction sector has seen significant and unprecedented growth in the last decade (Filardo et al. 2006; Abramson 2007; Agron 2007). A recent analysis reports that the nation's public school districts spent more than $\$ 500$ billion for capital between 1995 and 2004, building more than 12,000 new schools and managing more than 130,000 renovation and other improvement projects to existing schools (Filardo et al. 2006). Between 2000 and 2007, school construction expenditures across the country consistently exceeded record levels (Abrahamson 2007). Despite this enormous investment, little tracking or analyses of costs and spending have been conducted, though many school districts continually struggle to pay for new schools.

Given the extent of public dollars being invested in new public schools across the country, it is no surprise that the cost of school construction is making headlines. Rising capital costs are negatively affecting districts' ability to provide the promised schools. In California, the Orange County Register (June 18, 2006) found that due to cost increases, only six of 19 local school districts that passed construction bonds since 1990 (totaling $\$ 1.7$ billion) were delivering every project promised in their original bond. Two-thirds of these districts were being forced to scale back. As noted by one superintendent, "You tell me how we can do all the work we needed when construction costs go up by $30 \%$ across the board?" Homeowners become reluctant to increase their property taxes to pay for new schools. The Indiana legislature, for example, debated a bill that sought to help taxpayers control school construction costs and reduce debt service payments on new facilities by creating standardized plans - the rationale being that such a strategy would eliminate some significant architectural design fees on each project. Most recently, the Seattle Times reported that their school district has predicted that construction costs will rise 30\% over the next three years (January 14, 2008).

Despite the dramatic effects costs are having on local school districts and communities, little research has been done on the determinants of school construction costs. School facilities, in addition to being large complex structures, are public and tend to have greater regulatory controls placed upon them compared to other construction projects. As a result, practitioners have argued that this makes them inherently more expensive than building comparable private-owned buildings (Vincent and McKoy 2008). Moreover, evolving trends in educational facility requirements, such as early childhood education, smaller 
class sizes, social services, various supports for students, and the use of new instructional technologies, make school design and construction more complex. One of the primary reasons for which empirical research is limited is that data on school construction expenditures are difficult to obtain and data on school facilities themselves are limited.

This article addresses two of the above research concerns. It presents a comprehensive data set linking project-level school construction data to U.S. Census and other secondary data sources. Second, it isolates the impact of various school construction regulations in three models of construction costs, models that extend and improve upon previous attempts.

Findings confirm some previously understood relationships regarding costs and shed new light on the impact state-level policies have on school construction costs. We show that state-level regulations have large and significant impacts on school construction costs. An index of regulation, the School Construction Regulation Index (SCRI), shows that when the impacts are considered as additive, for each additional regulation on the books in a state, schools cost $11 \%$ more to build on average. However, models with dummy variables representing different combinations of regulations show that the relationship is more complex, and driven in large part by states with all three regulations. These states have school construction costs that are almost 30\% higher than those with none of the three regulations considered. Given the interactions of the regulatory variables in our different models, we conclude that rather than understanding the impacts of individual regulation as contributing to marginal increases in costs for each additional regulation, it is the whole regulatory environment of a place that have complex impacts on costs.

\section{RESEARCH ON THE COST OF SCHOOL CONSTRUCTION}

Few academic researchers have investigated school construction costs. Most analysis comes from the construction industry itself and focuses on changes in materials costs and mean regional or state-level square foot costs. The absence of detailed school construction cost data poses a major challenge to researchschool district capital budgets are largely unreported in much detail, unstudied, and poorly understood. Few states report these data beyond aggregate spending totals. Much of the difficulty in gathering school construction data lies in the fact that school construction costs are often not adequately or consistently tracked and/or reported. In states where this is the case, these procedures are typically too new to allow for any longitudinal analysis of cost trends. The second issue is making sure that costs are being compared adequately. Construction costs can be categorized in numerous ways, therefore, comparison across sources 
can be difficult and lead to misinterpretation. For example, the local or state definitions of what is included in "hard" and "soft" costs vary. When looking at construction bid data, which is collected by private firms in the construction industry, it is often not clear whether these data reflect the contract price at the start of construction or the final construction expense. These two numbers may differ in the event of construction change orders and/or other cost over-runs during the course of a project.

While quantitative research on school construction is limited, much analysis is done regularly on the overall construction industry. Most analysis points to general construction industry growth or decline and the related effects on materials and labor costs. Like school construction, the overall construction industry nationally was also in a boom cycle through the late 1990s and into the mid 2000s. The result of this massive construction activity has been that both labor and materials have been in high demand, especially in rapidly growing regions, which ultimately leads to labor and materials price increases. For example, Producer Price Index (PPI) data reveal about a 40\% increase nationally in construction materials costs alone between 2000 and 2006, and construction materials have continued to increase in cost more than the overall rate of inflation since 2004 (Simonson 2006). Construction wages were also on the rise across the country (Saylor 2007).

Additionally, many argue that public construction work, such as school construction, is fundamentally different from private construction work because they follow different rules under state policy (Vincent and McKoy 2008). Regulations on public construction differ by state, whereby school construction quite often follows its own unique set of state standards and regulations. Many critics of school construction costs in California, for example, point to the state's unique set of policies on school construction that substantially increase capital costs (Little Hoover Commission 2000; Billingsley 2005).

While a few academic researchers have studied school construction costs, most of the focus has been on the effects created by prevailing wage laws (PWL). PWLs set minimum pay and benefits for all workers on any public construction project. While all states must adhere to the federal Davis-Bacon Act, only 25 states have PWLs that are specific to school construction-a circumstance that has led to debate of the affect of PWL on school construction costs (Associated Builders and Contractors 2007). Critics of PWLs contend that they inherently increase the cost of school construction because they established a defacto minimum cost of labor. For example, one survey of contractors found that respondents alleged that school districts would save about $12 \%$ on construction costs were the Washington state law repealed (Washington Research Council 1999). An early study found significant cost increases (26-38\%) due to PWL (Fraundorf et 
al. 1984), although a more recent study found little to no statistical effect (AzariRad et al. 2003). Other studies have also found no significant increase in school construction costs associated with PWLs laws among mid-Atlantic states (Prus 1999) and midwestern states (Philips 2001).

Research has also been reported regarding the role project labor agreements (PLAs) have had on construction costs. A PLA is a pre-negotiated agreement between a project owner and local labor unions setting rules on a project, such as that all workers hired will be union members or that any non-union workers will pay union dues while they work on the project. Proponents of PLAs argue that PLAs open communication, reduce disputes and delays, ensure fair pay, and ultimately reduce costs. Opponents argue that PLAs establish cumbersome requirements, discourage non-union contractors from bidding, and result in increased project costs. Researchers have found that PLAs increase the cost to build schools by 14 to 18\% (Bachman et al. 2003; Bachman et al. 2004; Bachman and Tuerck 2006).

Finally, studies have attempted to assess the effect between school size and local construction climate on school construction costs. The recent pedagogical move by many school districts towards creating smaller schools to improve student performance has raised questions of the impact smaller schools have on capital costs. Larger schools have long been believed to give economy of scale benefits to school districts with conventional wisdom suggesting that smaller schools will be more expensive to build and maintain. However, Howley (2005) found that while school size largely predicted cost variances, smaller schools were no more expensive per student, and less expensive per square foot than larger schools. Also, Azari-Rad and others (2002) found that increased market crowding-that is, more school construction projects occurring simultaneously in a locality-does contribute to increased school construction costs, by about $4 \%$.

Research to date has been already hampered by a lack of data on the characteristics of newly built schools. All the previously mentioned factors are important determinants of construction costs, however, most studies are not able to appropriately control for other determinants of construction costs, such as design features or materials in school structures that make building more expensive. Models that do not consider these characteristics, or attempt to include proxies for them, suffer from potentially biased coefficients due to omitted variables.

\section{DATA ON SCHOOL CONSTRUCTION COSTS}

To better understand school construction costs across the country, and evaluate the impact of state regulations on capital costs, a unique dataset on new public 
school construction projects from all 50 states and the District of Columbia from 1995 to 2004 developed by the national Building Educational Success Together (BEST) collaborative was used. Because there are no comprehensive public data on public school construction spending, BEST utilized raw data provided by McGraw-Hill Construction, a segment of McGraw-Hill Companies, which collects detailed project-level data on every building project (new, renovations, and additions) valued at more than $\$ 100,000$ undertaken by the nation's school districts. $\mathrm{BEST}^{\star}$ analyzed the McGraw-Hill data and linked it to other datasets for their report, Growth \& Disparity: A Decade of U.S. Public School Construction (Filardo et al. 2006), which represents the most robust national dataset available on public school construction at the project level.

These "construction start" data reflect the contract value, or accepted bid price, of each project and represent the construction hard costs-the basic labor and material expenses of the project. The additional change orders and soft costssuch as site acquisition, architectural, engineering, and project managementare not collected by McGraw-Hill. Hard costs typically account for about 70\% of a project's total cost, although this can vary by project and locale. Therefore, it is important to note that in this study we analyze the hard construction costs for new schools as provided in the McGraw-Hill data as a measure of final costs.

New school construction projects were identified in the BEST data by analyzing the project descriptions contained in the data. Approximately 10,000 $(9,813)$ new school construction projects were identified. These projects were matched to National Center for Education Statistics (NCES) Common Core Data (CCD) and U.S. Census data and a total of 2,645 projects were successfully matched to these datasets. ${ }^{1}$ A review of the CCD indicates that 20,840 schools were opened (but not necessarily constructed) during the period from 1995 to 2004; thus, the matched data provide a minimum of a $15 \%$ sample. $^{2}$

These data show that capital costs have increased. Summarized in Figure 1, all new construction projects reported by McGraw-Hill Construction, show that the total cost of bids for school construction more than doubled between 1994 and 2004, from roughly $\$ 15$ billion to slightly less than $\$ 35$ billion annually. ${ }^{3}$ Simultaneously, the annual number of projects did not increase significantly; thus, the mean project cost also doubled.

In addition to a flat-percentage increase for school construction costs during this decade, regulations on school construction have also been argued to have had cost effects. The literature points to three key state-level regulations that may affect school construction costs: (1) whether a state funds school construction,

\footnotetext{
* Hereafter referred to as "BEST data"
} 


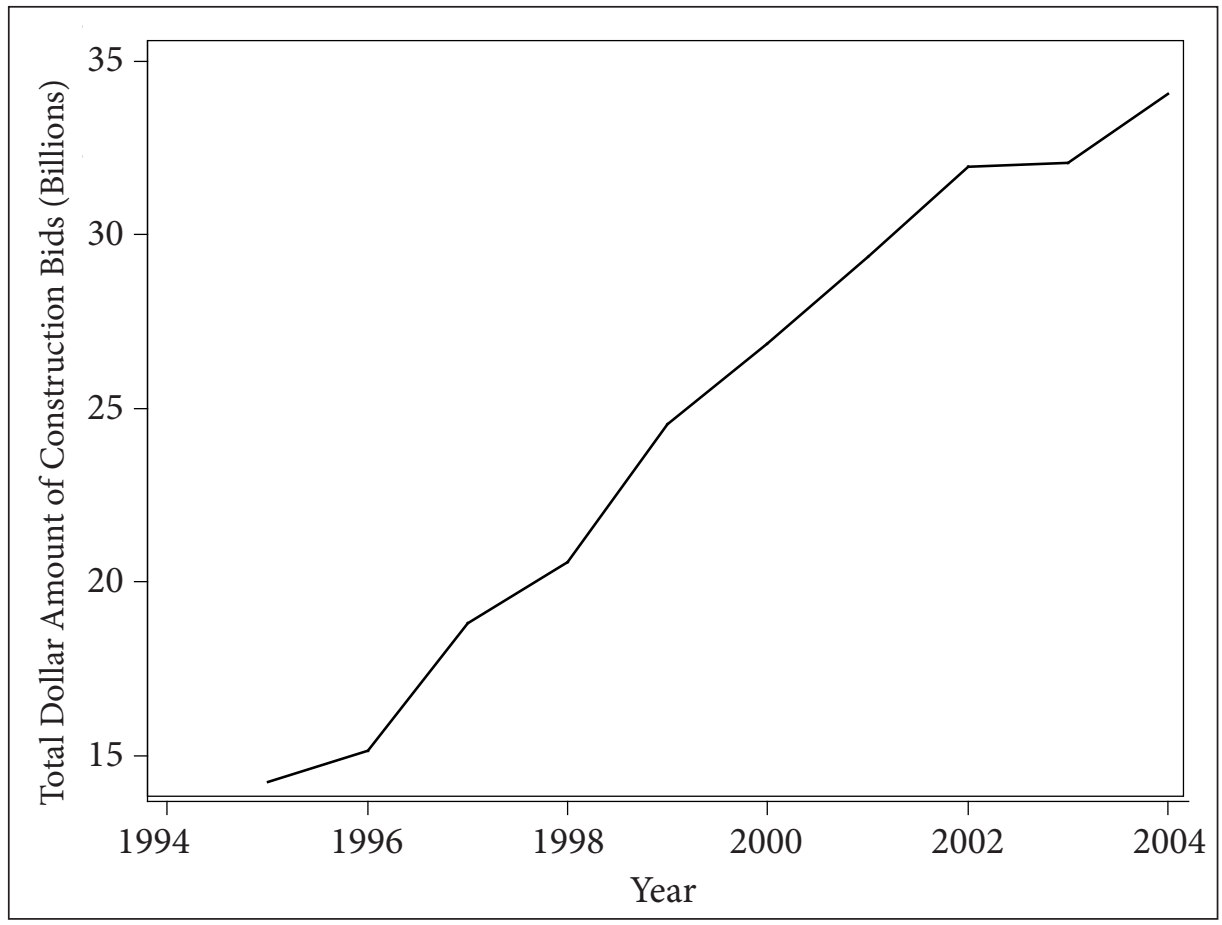

Figure 1. Expenditures on School Constructions Projects in the United States, 19952004 (Source: McGraw-Hill).

(2) whether a state has school siting laws, and (3) whether a state has a prevailing wage law for school construction. Because the presence of state school construction funding often comes with state regulation, school districts must follow to ensure accountability (Filardo 2007). We hypothesized that whether or not a state provided school construction funds would be an important variable. Because siting laws may limit a school district's choices when looking for new school sites, siting laws may ultimately affect costs in later stages of a project (Center for Cities \& Schools and American Architectural Foundation 2007). For example, some states have laws about allowable toxicity levels on school sites or how close these sites can be to airports, freeways, railroad tracks, and other infrastructure. As a result, in some cases schools may be located on sites that are not the most cost efficient to build upon from a construction perspective, although they are viewed as more appropriate school locations from a state policy perspective. The aforementioned prevailing wage laws have been debated in the literature as to whether or not they have significant effects on school construction cost (Fraundorf et al. 1984; Washington Research Council 1999; Prus 1999; Philips 2001; Azari-Rad et al. 2003).

Reported in Table 1 are the number of states where the state at least partially 
Table 1. Number and Percent of States ${ }^{\star}$ and Average School Construction Cost by School Construction Regulations

\begin{tabular}{llll}
\hline \multirow{2}{*}{ Regulation } & $\begin{array}{l}\text { Number of } \\
\text { States with } \\
\text { Regulation }\end{array}$ & $\begin{array}{l}\text { Percent of } \\
\text { States with } \\
\text { Regulation }\end{array}$ & $\begin{array}{l}\text { Mean Cost (2005 } \\
\text { Dollars per } \\
\text { Square Foot) }\end{array}$ \\
\hline State Funds School Construction & 16 & 31 & 164 \\
School Siting Laws & 19 & 37 & 170 \\
Prevailing Wage Law & 25 & 49 & 178 \\
All States & NA & NA & 160 \\
\hline
\end{tabular}

* Includes the District of Columbia.

funds school construction (Filardo 2007; Beaumont 2003), number of states with school siting laws (Rhode Island Legal Services 2005), and number of states where there are prevailing wage laws for public school construction (Associated Builders and Contractors 2007), along with the mean cost of school construction in those states. The regulations have roughly similar prevalence, less than $50 \%$ of the states have them, though prevailing wage laws are the most common. States with prevailing wage laws have higher mean construction costs than those without. However, these simple means can mask a number of factors that influence construction costs, such as school size, materials, and mean wages overall. Furthermore, most states have more than one regulation, and it is important to consider the whole regulatory environment when testing for the effects of regulations.

In order to measure the regulatory environment for school construction, a SCRI is created by summing the number of regulations present in a given state. Table 2 reports the SCRI by state, as well as the mean cost of school construction by SCRI. As indicated, the vast majority of states have at least one of the three

Table 2.Number and Percent of States* and Average School Construction Cost by School Construction Regulation Index

\begin{tabular}{rccc}
\hline SCRI & Number of States & Percent of States & $\begin{array}{l}\text { Average Cost } \\
\text { (2005 Dollars per Square Foot) }\end{array}$ \\
\hline 0 & 5 & 10 & 120 \\
1 & 14 & 27 & 134 \\
2 & 17 & 33 & 140 \\
3 & 15 & 29 & 203 \\
\hline
\end{tabular}

* Includes the District of Columbia. 
regulations, and most have more than one. The mean cost of school construction is slightly higher in states with one or two regulations than in states with zero, but the largest difference is found in states with three regulations. In these states, the mean cost of construction is more than one third higher than in states with none of the three regulations.

Reported in Table 3 are summary statistics for other data used in the present analysis. The mean school was roughly 90,000 square feet and between one and two stories tall. More than $50 \%$ of the schools constructed during the study decade were elementary schools and approximately 15\% were high schools. We later use the natural log of the project size to measure cost savings from economies of scale. There is a wide variation in the locality characteristics of new school projects. The population density of a school's locale is measured by thousands of people per square mile in the zipcode in which a school is built. The mean county level 2004 construction wage is used to capture differences in local wages. To capture local and regional school construction activity at the time a project is built, we constructed a variable that measured the total school construction expenditures (new and renovations/additions) by all school districts within each state the year before, year of, and year after the specified project, normalized by state population.

Table 3. Summary of National Data on Newly Built Schools and Localities

\begin{tabular}{|c|c|c|c|c|}
\hline School Characteristics & Mean & Std. Dev. & Min. & Max. \\
\hline Cost (2005 dollars per square foot) & 160.07 & 103.81 & 90.00 & 1932.42 \\
\hline Size (thousands of square feet) & 92.36 & 67.34 & 10.08 & 510.00 \\
\hline Stories Above Grade & 1.42 & 0.86 & 0.00 & 25.00 \\
\hline Stories Below Grade & 0.02 & 0.15 & 0.00 & 2.00 \\
\hline Intermediate School & 0.26 & 0.44 & 0.00 & 1.00 \\
\hline High School & 0.15 & 0.36 & 0.00 & 1.00 \\
\hline Locality Characteristics & Mean & Std. Dev. & Min. & Max. \\
\hline Construction Wage, 2004 & 44.98 & 13.05 & 6.83 & 98.40 \\
\hline $\begin{array}{l}\text { Population density } \\
\text { (thousands per square mile) }\end{array}$ & 2.17 & 5.81 & 0.00 & 97.72 \\
\hline $\begin{array}{l}\text { Three-Year Construction Activity } \\
\text { (billions of dollars) }\end{array}$ & 3.24 & 2.93 & 0.03 & 12.80 \\
\hline
\end{tabular}

Sources: McGraw-Hill, National Center for Education Statistics, and the U.S. Census 
MODELS OF THE DETERMINANTS OF SCHOOL CONSTRUCTION COSTS

The models presented in this section extend previous research in two ways. They include a more comprehensive set of independent variables than previous models, in order to control for and test the effect of various school characteristics and local conditions on school construction costs. The importance of including school characteristics in a model of construction costs cannot be understated. If a model omits important variables-in this case aspects of school facilities that impact construction costs such as pools-then there is a potential for endogeneity bias, where coefficients of variables that are associated with the omitted variable seem larger or smaller than their true value. In the present case, for example, if schools built in states with stringent regulations were more likely to have swimming pools, and swimming pools increased costs significantly, by omitting this information from the model, the coefficient on regulatory stringency would be biased upwards.

Additionally, by considering an index of regulatory stringency, the SCRI, as well as different combinations of regulations in different states, we are able to more accurately assess the impact of a state's regulatory environment on school construction costs. For example, the impact of state prevailing wage laws should not be analyzed in isolation from other regulations on school construction, as in practice, all regulations will hold for a given project.

Thus, to determine the factors that affect school construction costs, we use the model:

$$
\begin{aligned}
\ln \text { Cost }_{\mathrm{i}}= & \alpha_{\mathrm{i}}+\beta_{1} \text { School Characteristics }_{\mathrm{i}}+\beta_{2} \text { Locality Characteristics }_{\mathrm{i}}+ \\
& \beta_{3} \text { School Construction Activity }_{\mathrm{i}}+\beta_{4} \text { SCRI }_{\mathrm{i}}+\varepsilon_{\mathrm{i}}
\end{aligned}
$$

School Characteristics include the natural $\log$ of the square feet of a project, the stories above and stories below grade, the school type, and dummy variables for intermediate and high school (with primary school as the default). Locality Characteristics are the population density and the natural log of construction wage. School Construction Activity, as previously mentioned, is the natural log of the dollar value of all school construction work in the state for a three-year period around the data a bid was accepted. SCRI is the cumulative number of regulations present in a state. In this model, $\alpha_{\mathrm{i}}$ is the constant, or intercept, term.

In addition to the model, we run an identical model with a set of fixed effects for the year in which the school was built. Fixed effects refer to a model that includes dummy variables for each year, controlling for the impact of heterogeneity in these groupings not captured by other variables. The inclusion of year fixed effects controls for fluctuations in the business cycle. The fixed effects model is as follows: 
$\ln \operatorname{Cost}_{\mathrm{it}}=\alpha_{\mathrm{i}}+\beta_{1}$ School Characteristics $_{\mathrm{it}}+\beta_{2}$ Locality Characteristics $_{\mathrm{it}}+$

$\beta_{3}$ School Construction Activity ${ }_{i t}+\beta_{4}$ Regulatory Index (SCRI) ${ }_{i t}+\varepsilon_{i t}$

All variables are included as in equation (1) as well as the set of fixed-effects variables. Thus, the $\alpha_{i}$ is not the constant in these models; rather, it can be thought of as base value for the omitted year.

\section{RESULTS}

The results from the two models are reported in Table 4, which uses the SCRI as a measure of regulatory stringency. Model A does not include year fixed effects but Model B does. The models use national data, encompassing 2,645 projects,

Table 4. Regression Results of the Determinants of School Construction Costs (Dependent Variable: Log of Cost per Square Feet)

\begin{tabular}{lll}
\hline Variables & Model A & Model B \\
\hline Square feet $(\ln )$ & -0.179 & -0.175 \\
Stories Above Grade & {$[0.014]^{* *}$} & {$[0.014]^{* *}$} \\
Stories Below Grade & 0.028 & 0.030 \\
& {$[0.009]^{* *}$} & {$[0.008]^{* *}$} \\
Intermediate School & 0.182 & 0.177 \\
& {$[0.056]^{* *}$} & {$[0.054]^{* *}$} \\
High School & 0.075 & 0.076 \\
& {$[0.016]^{* *}$} & {$[0.016]^{* *}$} \\
Population Density, 2000 $\dagger$ & 0.142 & 0.141 \\
Construction Wage, $2004(\ln )$ & {$[0.022]^{* *}$} & {$[0.022]^{* *}$} \\
Construction Activity $\dagger \dagger(\ln )$ & 0.012 & 0.013 \\
SCRI & {$[0.002]^{* *}$} & {$[0.002]^{* *}$} \\
Adjusted-R ${ }^{2}$ & 0.210 & 0.203 \\
\hline F-statistic & {$[0.021]^{* *}$} & {$[0.021]^{* *}$} \\
\hline
\end{tabular}

Notes: White robust standard errors in brackets. ${ }^{\star}$ Indicates significance at the 0.05 level, ${ }^{\star *}$ indicates significance at the 0.01 level. $\dagger$ Population density is in thousands of people per square mile. $\dagger \dagger$ Construction activity is normalized by state population. 
and are statistically significant as indicated by the F statistic. Consistent with previous studies, we find that a project's total cost is largely explained by project size. A simple bivariate model regressing project size on total cost has an adjusted $\mathrm{R}^{2}$ of more than 0.60 . Thus, it is no surprise that using cost per square foot as the dependent variable yields a much lower explanatory power-between .32 and 0.33 . All coefficients are statistically significant at conventional levels, and have the expected signs.

Project-level characteristics have important cost impacts that, other than the measure of construction activity, do not change significantly in the fixed-effects model. This is logical because cost heterogeneity of different years should not affect project-level characteristics such as the impact of extra floors. The first variable, school size, measures economies of scale which are large. For each 10\% increase in the square footage of a school, costs per square foot drop by almost $2 \%$. Each additional story added to a project adds nearly 3\% to the square foot cost. A basement adds roughly $18 \%$ to the cost. Both intermediate schools and high schools were found to be more expensive per square foot compared to elementary schools-about $7 \%$ and $14 \%$ respectively. These coefficients are consistent across the two models. The higher square foot cost for intermediate and high schools is likely due to the more sophisticated spaces, such as gymnasia, swimming pools, and science labs needed to accommodate high school curriculums. These actual physical project characteristics are an important aspect of school construction costs that can only be addressed by proxy at this point.

Local factors also had a significant impact on construction costs, especially construction wages. The population density of the zip code in which a school is built, which is intended as a proxy for the increased costs of building in more urban areas, affects school construction by a small but significant amount. For each additional thousand people per square mile, costs increase by $1 \%$ per square foot. ${ }^{4}$

The final two variables measure state-level factors affecting school construction costs-three-year construction activity and the SCRI. Research on school construction costs has argued that as more school construction projects are undertaken in a given region or state, competition decreases because builders are occupied and the size of bids increases (Vincent and McKoy 2008; Azari-Rad et al. 2002). Construction activity, as measured by the dollar value of projects occurring in a state in a three-year period around the bid date of a given project, has an important impact on the cost per square foot of a project. A $10 \%$ increase in the dollar value of bids in a three-year period increases costs by about $6 \%$; however, when year fixed effects are included, the coefficient is not significant. This suggests that the impact of the business cycle is greater than that of builder supply. The SCRI, which measures the number of regulations in a given state, 
has a statistically significant and large coefficient-each additional regulation in a state raises school construction cost per square foot by about $11 \%$.

Although treating the impact of regulations as additive yields significant results, it is likely that the cumulative impact of regulation is not linear. As shown in Table 2, states with all three regulations have much higher construction costs than those with two or one. Thus, additional models were run which included dummy variables for states with one, two, and three regulations. Table 5 reports the coefficients on these SCRI dummy variables. It is evident from these results that the relationship between state regulation and construction costs is not linear; rather, the pattern outlined in Table 2 persists even after controlling for school and locality characteristics. States with three regulations have construction costs that are almost 30\% higher than those states with zero regulations, and construction costs in states with two regulations are only statistically higher than those with zero in the second model, and the coefficient is smaller for states with one regulation.

Table 5. The Impact of Multiple Regulations on School Construction Costs (Dependent Variable: Log of Cost per Square Feet)

\begin{tabular}{cll}
\hline Number of Regulations & Model A & Model B \\
\hline \multirow{2}{*}{1} & 0.061 & 0.069 \\
& {$[0.028]^{*}$} & {$[0.028]^{* *}$} \\
2 & 0.049 & 0.057 \\
& {$[0.025]$} & {$[0.026]^{*}$} \\
3 & 0.291 & 0.296 \\
& {$[0.027]^{* *}$} & {$[0.027]^{* *}$} \\
\hline
\end{tabular}

Notes: Coefficients are taken from models equivalent to those reported in Table 4. Base case is states with 0 regulations. White robust standard errors in brackets.

${ }^{\star}$ Indicates significance at the 0.05 level, ${ }^{* *}$ indicates significance at the 0.01 level.

The models presented in Tables 4 and 5 do not distinguish between the impact of specific regulations or combination of regulations; yet, it is likely that some laws have a larger impact on construction costs than others. Table 6 presents the coefficients on dummy variables indicating the presence of individual regulations in states, in regressions equivalent to those presented in Table 4. Laws mandating the state funding of school construction do not have statistically significant effect on construction costs. Laws mandating prevailing wages and school siting do, however, increasing construction costs by 13 and 12\% each. It is surprising to find that laws governing school siting have a similar impact as prevailing wage laws given the attention paid to the latter in the literature. 
Table 6. The Impact of State Regulations on School Construction Costs (Dependent Variable: Log of Cost per Square Feet)

\begin{tabular}{lll}
\hline Regulation & Model A & Model B \\
\hline State Funds School Construction & 0.071 & 0.076 \\
& {$[0.015]^{\star *}$} & {$[0.016]^{\star *}$} \\
State Siting Laws & 0.128 & 0.124 \\
& {$[0.013]^{\star *}$} & {$[0.012]^{\star *}$} \\
Prevailing Wage Law & 0.131 & 0.134 \\
& {$[0.013]^{\star *}$} & {$[0.013]^{\star *}$} \\
\hline
\end{tabular}

Notes: Coefficients are taken from models equivalent to those reported in Table 4 . White robust standard errors in brackets. ${ }^{\star}$ Indicates significance at the 0.05 level, ${ }^{* *}$ indicates significance at the 0.01 level.

Because half of the states have prevailing wage laws for school construction, the sample was divided into two sets to test whether the effects of the remaining two regulations are similar in both halves. Not surprisingly, the variation in wage has a much larger effect in the group of states that have prevailing wage laws.

Finally, in order to better understand the impact of multiple state regulations on construction costs, regressions were run that include seven dummy variables for all combinations of regulations at the state level-state funding laws, prevailing wage laws, siting laws, funding and prevailing wage, funding and siting, siting and prevailing wage, and all three. ${ }^{5}$ Table 7 presents mean square foot construction costs-the number of schools by category and coefficients for the 7 combinations of regulations in regressions equivalent to those in Table 4 .

The inclusion of dummy variables for all combinations of regulations shows that the effect of regulation on school construction costs is more complicated than our previous models (and previous research) suggests. Many of the combinations of state regulation do not significantly impact the costs of construction. Costs in states that only have school siting and prevailing wage laws do, with a similar impact of between $8 \%$ and $9 \%$. The one school built in Montana, the only state with both prevailing wage and siting laws was also roughly 10 to $12 \%$ more expensive than the schools built in states with none of the three regulations. Schools built in states with laws mandating both state funding of school construction and prevailing wages are not significantly more expensive than those built in states with no regulations, though it bears mention that roughly $98 \%$ of these schools were built in one of the three states in this category, Texas.

Nevertheless, the principal finding remains true-schools built in states with all three regulations continue to cost almost 30\% more than those built in states 
Table 7. The Impact of Combinations of State Regulations on School Construction Costs (Dependent Variable: Log of Cost per Square Feet)

\begin{tabular}{|c|c|c|c|c|}
\hline Regulations & $\begin{array}{c}\text { Cost per sq. } \\
\mathrm{ft.}(\$)\end{array}$ & $\begin{array}{c}\text { Number of } \\
\text { Schools }\end{array}$ & Model A & Model B \\
\hline None & 119.8 & 115 & NA & NA \\
\hline State Funds Construction & 116.8 & 101 & $\begin{array}{l}-0.32 \\
{[0.032]}\end{array}$ & $\begin{array}{l}-0.026 \\
{[0.032]}\end{array}$ \\
\hline State Siting Laws & 134.9 & 131 & $\begin{array}{l}0.079 \\
{[0.037]^{\star}}\end{array}$ & $\begin{array}{l}0.085 \\
{[0.038]^{\star}}\end{array}$ \\
\hline Prevailing Wage Law & 150.7 & 274 & $\begin{array}{l}0.087 \\
{[0.031]^{\star *}}\end{array}$ & $\begin{array}{l}0.095 \\
{[0.031]^{\star *}}\end{array}$ \\
\hline Funds \& Siting & 141.0 & 867 & $\begin{array}{l}0.061 \\
{[0.026]^{\star}}\end{array}$ & $\begin{array}{l}0.067 \\
{[0.026]^{*}}\end{array}$ \\
\hline Funds \& Wage & 134.1 & 329 & $\begin{array}{l}0.014 \\
{[0.029]}\end{array}$ & $\begin{array}{l}0.027 \\
{[0.030]}\end{array}$ \\
\hline Wage \& Siting & 110.5 & 1 & $\begin{array}{l}0.122 \\
{[0.035]^{\star *}}\end{array}$ & $\begin{array}{l}0.096 \\
{[0.036]^{\star}}\end{array}$ \\
\hline Funds, Wage \& Siting & 202.6 & 916 & $\begin{array}{l}0.292 \\
{[0.027]^{* *}}\end{array}$ & $\begin{array}{l}0.297 \\
{[0.027]^{* \star}}\end{array}$ \\
\hline
\end{tabular}

Notes: Coefficients are taken from models equivalent to those reported in Table 4. Base case is those states with all 3 regulations. White robust standard errors in brackets. ${ }^{\star}$ Indicates significance at the 0.05 level, ${ }^{* *}$ indicates significance at the 0.01 level.

with none of the three regulations. However, schools built in states with any two regulations were still $23-27 \%$ more than schools built in states with no regulations. Based on these findings, we conclude that rather than understanding the impacts of individual regulation as contributing to marginal increases in costs for each additional regulation as previous research has focused, it is the whole regulatory environment of a place that has complex impacts on costs. In other words, there may not be a regulatory "silver bullet" to reducing school construction costs, which ultimately help determine construction costs.

\section{CONCLUSION}

Despite the enormous amounts of public dollars being spent on new schools and the dramatic effects cost escalation is having on local school districts, little research has investigated the importance of the various factors that determine school construction costs. Between 1995 and 2004, the nation's public school districts spent more than $\$ 500$ billion dollars on capital expenses. As states and 
local districts increase their capital investments to meet the demand to replace decaying facilities in older neighborhoods and build new ones in growing areas, research is needed to examine these investments and offer recommendations to guide effective public spending to build high-quality school buildings in the most fiscally responsible manner.

As researchers look to make headway into understanding school construction costs, data availability and measurement poses a major obstacle. First, more systematic data collection systems are needed because data on school construction costs are not currently or widely available. Second, these data must be more comprehensive than the hard construction data (accepted contract bid price), such as that collected by McGraw-Hill. One important concern is that using accepted bid price as a measure of project cost may be inappropriate to assess the impact of most variables. This may be particularly true for assessing policies such as PWLs, because these data do not account for the prevalence or absence of change orders after a construction bid has been accepted, which can greatly affect total project cost. Some proponents of PWLs assert that their presence increases skilled workmanship and decreases change orders, thereby making the contract bid price and the final hard construction cost on a nonPWL to be significantly different.

We conclude with three key research advances that are needed in the study of the cost impacts of state regulation. First, analysis should incorporate more detailed project-level data on each school. Studies that do not include enough school characteristic data may over attribute costs to regulations, as Belman and others (2005) found in relation to project labor agreements. Akin to hedonic models of house prices, omitted variables can cause significant bias in coefficient estimates, depending on their association with variables included in the models. Additionally, other local factors should be measured, such as regional or state union "density" or "strength," which might play a significant role in determining construction costs. Second, we caution that continued analysis of the cost impacts of state regulation needs to measure these against the benefits of the better "product" in which these regulations may result. Though we do not devote much space to this point, it is clear that when debating the impact of regulations on school construction, their cost impacts must be compared with their effects on safety, equity, and design for all students-particularly because research has shown that school facility quality has a variety of impacts on students, teachers, and school quality (Schneider 2002; Higgins et al. 2005). Third, a better understanding of the interactions among regulations within a state's whole regulatory environment is needed. Such analysis should investigate not only the ways in which regulations interact, but also the ways in which regulatory environments affect locally made school construction decisions. 


\section{References}

Associated Builders and Contractors. (2007). States without Prevailing Wage Laws for School Construction. Available: http://www.abc.org/wmspage.cfm?parm1=2142, last accessed 3/15/08

Azari-Rad, H., Philips, P. and Prus, M. (2003). State Prevailing Wage Law and School Construction Costs. Industrial Relations, 42(3), 445-457.

Azari-Rad, H., Philips, P. and Prus, M. (2002). Making Hay When It Rains: The Effect of Prevailing Wage Regulations, Scale Economies, Seasonal, Cyclical and Local Business Patterns Have on School Construction Costs. Journal of Education Finance, 27, 997-1112.

Bachman P. and Tuerck, D.G. (2006). Project Labor Agreements and the Cost of Public School Construction in New York State. Cambridge, MA: Beacon Hill Institute at Suffolk University.

Bachman, P., Chisholm, D.C., Haughton, J. and Tuerck, D.G. (2003). Project Labor Agreements and the Cost of Public School Construction in Massachussetts. Cambridge, MA: Beacon Hill Institute at Suffolk University.

Bachman, P. and Haughton, J. (2004). Project Labor Agreements and the Cost of Public School Construction in Connecticut. Cambridge, MA: Beacon Hill Institute at Suffolk University.

Beaumont, C. (2003). State Policies for School Construction and Renovation. Washington, DC: National Trust for Historic Preservation.

Belman, D., Ormiston, R., Schriver, W., and Kelso, K. (2005). The Effect of Project Labor Agreements on the Cost of School Construction in New England. School of Labor and Industrial Relations, Michigan State University, Working Paper Series.

Billingsley, K.L. (2005). No Place to Learn. San Francisco: Pacific Research Institute.

Building Educational Success Together and Center for Cities \& Schools. (forthcoming). A Decade of California Public School Construction. Berkeley: Center for Cities \& Schools.

California Performance Review. (2004). Government for the People for a Change. INF 31 OneStop Shop for School Facility Approval. Available: http://cpr.ca.gov/report/cprrpt/issrec/inf/ inf31.htm, last accessed 3/15/08.

Carrick, A. (2007). Vocational Schools Carry the Highest Construction Costs among K-12 Schools. Building Team Construction Forecast. Available: http://www.buildingteamforecast. com/article/CA6479626.html?industryid=43720\&nid=2816, last accessed 3/15/08.

Carroll, S.J., Krop, C., Arkes, J., Morrison, P.A., and Flanagan, A. (2005). California's K-12 Public Schools: How Are They Doing? Santa Monica, CA: RAND Corporation.

Center for Cities \& Schools and American Architectural Foundation. 2007. Building Schools, Building Communities: The Role of State Policy in California. Berkeley, CA: CC\&S.

Filardo, M., Vincent, J.M., Sung, P., and Stein, T. (2006). Growth \& Disparity: A Decade of U.S. Public School Construction. Washington, DC: Building Educational Success Together.

Filardo, M. (2007). Personal communication with authors, December 12th and 15th. Filardo is the Executive Director of the 21st Century School Fund and the Building Educational Success Together (BEST) national collaborative.

Fraundorf, M., Farrell, J.P., and Mason, R. (1984). The Effect of the Davis-Bacon Act on Construction Costs in Rural Areas. Review of Economics and Statistics, February, 142-146.

Higgins S., Hall, E., Wall, K., Woolner, P., and McGaughey, C. 2005. The impact of school environments: A literature review. The Design Council, 47.

Howley, C.B. (2005). Don't Supersize Me: The Relationship of Planned Construction Cost to Planned School Enrollment in the U.S. Paper presented at the annual meeting of the International Society for Educational Planning, Bologna, Italy, October.

Izumi, L.T. and Cox, M. (2003). California Education Report Card: Index of Leading Education Indicators, Third Edition. San Francisco, CA: Pacific Research Institute.

Little Hoover Commission. (2000). To Build A Better School. Sacramento, CA: Little Hoover Commission. 
National Access Network, Teachers College, Columbia University. (2007). Available: http://www. schoolfunding.info/index.php3, last accessed 3/15/08.

Office of Public School Construction. School Facility Program, Statistical and Fiscal Data, December 16, 1998 through June 27, 2007. Available: http://www.documents.dgs.ca.gov/ OPSC/Resources/Stats_Fiscal_Data.pdf, last accessed 3/15/08.

Orange County Register. "Many schools getting less bang for bonds," by Perez, E., Miller, S., and Leal, F. June 18, 2006.

Ortiz, F.I. (2004). Essential Learning Conditions for California Youth: Educational Facilities. Teachers College Record, 106(10), 2015-2031.

Philips, P. (2001). A Comparison of Public School Construction Costs, In Three Midwestern States that have Changed their Prevailing Wage Laws in the 1990s: Kentucky, Ohio, and Michigan.

Philips, P. (2005). A Case Study of the East Side Union High school District 2004 Project Labor Agreement in San Jose, California.

Ponessa, J. (2007). Personal communication with authors, December 10th. Ponessa is research director for the New Jersey Education Law Center.

Prus, M.J. (1999). Prevailing Wage Laws and School Construction Costs: An Analysis of Public School Construction in Maryland and the Mid Atlantic States.

Rensselaer Republican. "Bill to Create Standardized Plans for School Facilities Proposed in Indiana." December 7, 2007.

Rhode Island Legal Services. (2005). Fifty State Survey of School Siting Laws, Regulations, and Policies. Available: http://www.childproofing.org/RIReport.htm, last accessed, 3/15/08.

Saylor, B. (2007). Construction Market Outlook and Cost Report Q1, 2007. Presentation at the Schools and Community Colleges in California, An Ad-Hoc Roundtable Discussion, hosted by Parsons. Los Angeles, CA. May 17.

Schneider, M. 2002. Do School Facilities Affect Academic Outcomes? Washington, DC: National Clearinghouse for Educational Facilities.

Seattle Times. "Seattle in Race to Fix Schools Before Construction Costs Soar," by Heffter, E. January 14, 2008.

Simonson, K. (2006). AGC's Construction Inflation Alert: Tracking the Surge in Construction Costs, 2001-2006. Associated General Contractors of America.

Vincent J.M. and McKoy, D.L. (2008). The Complex and Multifaceted Nature of School School Construction Costs: Factors Affecting California. Report to the American Institute of Architects, California Council. Berkeley: Center for Cities \& Schools.

Washington Research Council. (1999). Special Report: More and Better Schools with Repeal of Prevailing Wage Laws. Seattle, WA: Author.

\section{Endnotes}

1. When schools change names, or are subdivided into smaller schools, they are also recorded as new schools.

2. We conducted a distribution analysis of the schools in our sample and found it does not significantly under- or over-represent any one state compared to the entire population of schools, nor the newly added schools each year, as in the NCES data (differences were between -3 and 3 percent). Any selection bias that may be present would likely be a reflection of the national "completeness" of the McGraw-Hill school construction data. For example, it is assumed that McGraw-Hill collects complete data of all projects regardless of the level of local school construction activity.

3. The cost data in the BEST dataset were normalized to 2005 constant dollars for comparison using the Turner Building Cost Index, a national construction cost index that factors labor rates and productivity, material prices, and the competitive condition of the marketplace, in addition to inflation.

4. For comparison, San Francisco, CA, has a population density of 15,000 people per square mile, while that of Phoenix, AZ, is 3,000. 
5. A fourth indicator of state regulation was originally considered in the modeling effort, whether or not a state had successful litigation that involved remedying inequities in school facility conditions such as the Williams case in California or the Abbott line of cases in New Jersey. Nationally, by early 2008, 29 states had successful litigation of this type (National Access Network 2007; Ponessa 2007). We hypothesized that this variable may serve as an indicator of the strictness of regulation, as mandated by the courts. We found that states with successful litigation did tend to have higher school construction costs. However, the variable does not function as an independent variable because it suffers from simultaneity bias. 